\title{
PELATIHAN TERAPI SENSORI INTEGRASI LEVEL BASIC UNTUK GURU MADRASAH INKLUSI DI KABUPATEN LOMBOK BARAT
}

\author{
Arif Widodo $^{1}$, Khairunnisa ${ }^{2}$, Nurul Kemala Dewi ${ }^{3}$, Vivi Rachmatul Hidayati ${ }^{4}$, Ni Luh Putu Nina \\ Sriwarthini ${ }^{5}$, Hasnawati ${ }^{6}$ \\ 1,2,3,4,5,6 Universitas Mataram \\ E-mail: arifwidodo@unram.ac.id
}

\author{
Article History: \\ Received : 29-09-2020 \\ Revised : $12-10-2020$ \\ Accepted : 29-10-2020
}

\begin{abstract}
Kemampuan guru dalam memberikan layanan belajar terhadap anak berkebutuhan khusus belum maksimal, salah satunya dalam mengatasi hambatan belajar anak tuna grahita. Berdasarkan studi pendahuluan sebagian besar guru belum memiliki kompetensi untuk mengatasi hambatan belajar anak tuna grahita. Maka dari itu perlu diadakan pelatihan terhadap guru melalui kegiatan pengabdian masyarakat. Pelatihan yang diberikan adalah terapi sensori integrasi level basic. Tujuan kegiatan ini adalah agar guru mampu memberikan treatment yang efektif dalam mengatasi hambatan belajar anak tuna grahita. Lokasi pelatihan di MINW Tanak Beak, salah satu Madrasah inklusi di kabupaten Lombok Barat. Metode pemecahan masalah yang diberikan yaitu sosialisasi, edukasi dan simulasi. Solusi yang ditawarkan dalam kegiatan ini adalah menerapkan treatment terapi sensori integrasi secara mandiri dalam proses pembelajaran di kelas. Setelah kegiatan pelatihan selesai para guru diharapkan dapat menerapkan terapi sensori integrasi secara mandiri dengan baik sehingga hambatan belajar yang dialami anak tuna grahita dapat teratasi.
\end{abstract}

Keywords: terapi sensori integrasi, level basic, madrasah inklusi

\section{Pendahuluan}

Dewasa ini jumlah dan jenis anak berkebutuhan khusus semakin meningkat terutama pada anak usia sekolah dasar. Tidak semua anak berkebutuhan khusus mendapatkan hak pendidikan secara layak (Sriwarthini et al. 2020). Seiring dengan adanya program pendidikan inklusif dari pemerintah semakin banyak lembaga pendidikan yang berani menerima anak-anak berkebutuhan khusus (Wardani et al. 2020). Cita-cita education for all semakin terlihat di depan mata. Salah satu sekolah yang memiliki anak berkebutuhan khusus di daerah Lombok Barat adalah MI NW Tanak Beak. Jumlah anak berkebutuhan khusus di Madrasah ini berjumlah 54 siswa, 22\% diantaranya merupakan anak tuna grahita yang mengalami kesulitan belajar spesifik (Widodo, Haryati, et al. 2020). Hal ini tidak mengherankan mengingat sekolah ini merupakan satu-satunya madrasah inklusi di kabupaten Lombok Barat yang mendapat SK penyelenggaraan pendidikan inklusif dari Kementrian Agama. Namun demikian kesiapan guru 
dalam memberikan pelayanan terhadap kebutuhan khusus masih menjadi pekerjaan rumah madrasah inklusi yang harus diselesaikan.

Peran guru dalam memberikan layanan belajar terhadap anak berkebutuhan khusus sangat penting (Pujaningsih 2019). Namun demikian tidak sedikit masalah yang dihadapi para guru untuk memberikan layanan belajar yang maksimal. Salah satu peyebabnya banyak guru yang memiliki latar belakang pendidikan di luar pendidikan luar biasa (Wardah 2019). Para guru bahkan masih kesulitan dalam melakukan identifikasi kebutuhan khusus yang dialami oleh siswanya. Implikasinya program pendidikan inkklusi tidak sesuai harapan (Widodo 2020b). Hal ini sangat fatal, mengingat identifikasi kebutuhan khusus merupakan tahapan terpenting dalam mengenali anak berkebutuhan khusus (Fedulova et al. 2019). Bahkan seringkali identifikasi terhadap anak berkebutuhan khusus terlambat yang berpengaruh terhapap kemampuan sosialnya (Idris and Fitriani 2018). Dalam keadaan tertentu dapat mengarah pada penyimpangan perilaku (Widodo 2020a). Salah satu penyebabnya diantaranya adalah kurangnya kompetensi guru dalam memberikan layanan belajar kepada anak berkebutuhan khusus (Mayasari 2016).

Anak tuna grahita sebagai salah satu anak berkebutuhan khusus memiliki hambatan belajar spesifik. Salah satu cirinya adalah sulit melakukan konsentrasi dan membentuk fokus. Salah satu penyebabnya adalah tingkat kecerdasan anak jenis ini tergolong rendah. IQ rata-rata anak tuna grahita berkisar 50-80. Seperti halnya anak berkebutuhan khusus lainnya, anak tuna grahita memiliki karakteristik yang berbeda dengan anak pada umumnya. Masing-masing anak berkebutuhan khusus membutuhkan treatment yang berbeda sesuai dengan jenis kebutuhan yang dimilikinya (Widodo, Indraswati, et al. 2020). Permasalahannya adalah banyak diantara guru yang belum memiliki kemampuan dalam melakukan treatment kepada anak tuna grahita. Banyak diantara guru yang beranggapan bahwa hambatan belajar pada anak tuna grahita tidak dapat di atasi. Satu-satunya solusi adalah menurunkan KKM untuk anak tuna grahita. Kesulitan belajar yang dialami anak tuna grahita jika tidak diselesesaikan dapat berakibat buruk terhadap masa depannya.

Permasalahan tersebut merupakan hambatan serius yang dihadapi madrasah inklusi dalam memberikan layanan belajar yang optimal terhadap anak berkebutuhan khusus. Berdasarkan hasil studi pendahuluan dapat diketahui bahwa sebagian besar guru belum mengetahui treatment dalam mengatasi hambatan belajar pada anak tuna grahita. Meskipun di sekolah ini telah disediakan guru pendamping khusus (GPK), tetapi layanan terhadap anak tuna 
grahita belum maksimal. Hal ini dikarenakan sebagain besar dari guru kelas belum pernah mendapatkan pelatihan dalam menangani anak berkebutuhan khusus, termasuk dalam hal ini adalah anak tuna grahita. Masing-masing guru kelas perlu dibekali dengan kompetensi khusus dalam menangani anak tuna grahita agar kesulitan belajar yang dihadapi dapat teratasi.

Salah satu treatment yang dapat digunakan dalam mengatasi hambatan belajar anak tuna grahita adalah dengan menerapkan metode terapi sensori integrasi. Berdasarkan pada sebuah penelitian terapi sensori integrasi efektif dalam mengendalikan kondisi emosional dan memperbaiki gangguan fokus yang dialami oleh anak tuna grahita (Indah and Masitoh 2013). Penelitian serupa juga mengungkapkan bahwa terapi sensori integrasi dapat meningkatkan tingkat fokus dan kesulitan konsentrasi pada anak tuna grahita (Komariah 2018). Berdasarkan beberapa penelitian tersebut dapat disimpulkan bahwa penggunaan terapi sensori integrasi terbukti efektif dalam memperbaiki fokus dan tingkat konsentrasi yang menjadi hambatan belajar pada anak tuna grahita.

Berdasarkan latar belakang di atas maka pemberian pelatihan terapi sensori integrasi kepada guru sangat penting. Hal ini dikarenakan kompetensi guru dalam melakukan treatment terhadap anak tuna grahita masih kurang. Selain itu guru belum pernah mendapatkan pelatihan tentang penggunaan terapi sensori integrasi terutama dalam mengatasi hambatan belajar anak tuna grahita. Melalui pelatihan dalam program pengabdian masyarakat ini diharapkan guru memiliki kompetensi yang cukup dalam memberikan layanan belajar terhadap anak tuna grahita. Selain itu diharapkan adanya perubahan pola pikir bahwa hambatan belajar anak tuna grahita tidak dapat di atasi.

\section{Metode}

Kegiatan pengabdian masyarakat dilakukan oleh tim dosen dari program studi PGSD Universitas Mataram. Bentuk kegiatan dalam pengabdian masyarakat ini berupa pelatihan terapi sensori integrasi level basic. Subjek dalam kegiatan pengabdian masyarakat ini adalah para guru di madrasah inklusi. Lokasi pengabdian masyarakat di MI NW Tanak Beak, Kecamatan Narmada, kabupaten Lombok Barat. Metode dalam pengabdian masyarakat ini antara lain melakukan koordinasi, komunikasi, sosialisasi, pelatihan, dan praktik. Untuk mendapatkan hasil yang maksimal tim pengabdian masyarakat bekerjasama dengan salah satu pakar terapi sensori integrasi di kota Mataram. Dengan belajar terapi secara langsung dari ahlinya diharapkan para guru dapat memahami teknik terapi dengan baik. Tahapan terpenting 
setelah adanya pelatihan adalah tahapan aktualisasi. Diharapkan para guru dapat menerapkan dengan baik teori dan praktik yang telah didapatkan selama mengikuti pelatihan. Dengan menerapkan ilmu yang diperoleh melalui pelatihan diharapkan hambatan belajar pada anak tuna grahita dapat terselesaikan dengan baik. Untuk meudahkan dalam memahami alur kegiatan pengabdian masyarakat berikut ini dapat disajikan mekanisme pengabdian masyarakat yang telah dilakukan.

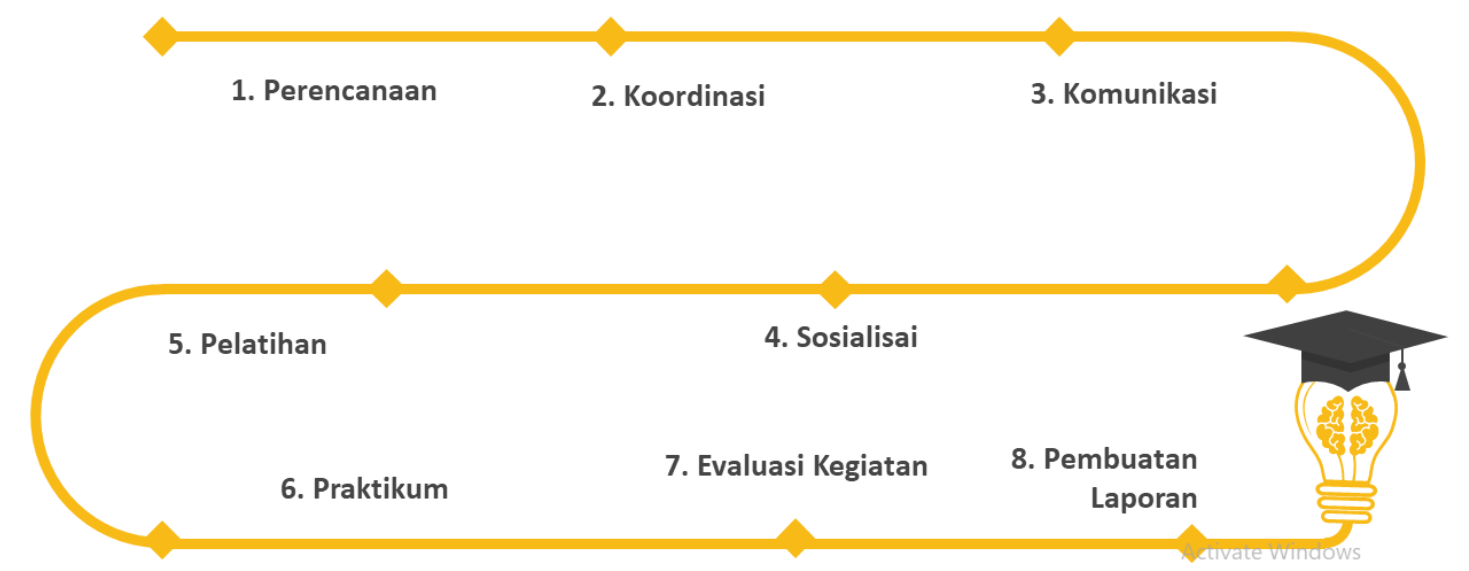

Gambar 1. Mekanisme Pengabdian Masyarakat

\section{Hasil}

Kegiatan pengabdian masyarakat secara keseluruhan dimulai pada bulan Maret sampai dengan Desember 2020. Hasil kegiatan dapat disajikan sebagai berikut:

Tabel 1. Tahapan Pengabdian Kepada Masyarakat

\begin{tabular}{|c|c|c|c|}
\hline No & Bulan & Nama Kegiatan & Deskripsi Kegiatan \\
\hline 1 & Maret & $\begin{array}{l}\text { Penentuan tema } \\
\text { pengabdian } \\
\text { masyarakat }\end{array}$ & $\begin{array}{l}\text { - } \text { Membentuk tem PKM } \\
\text { - Identifikasi permasalahan } \\
\text { sekolah mitra } \\
\text { - Menentukan tema PKM } \\
\text { - Pembuatan proposal PKM }\end{array}$ \\
\hline 2 & April-Mei & $\begin{array}{l}\text { Pengajuan } \\
\text { PKM }\end{array}$ & $\begin{array}{l}\text { - Kompetisi proposal tingkat } \\
\text { universitas } \\
\text { - Penandatanganan kontrak } \\
\text { PKM }\end{array}$ \\
\hline 3 & Juni & $\begin{array}{l}\text { Perencanaan } \\
\text { pelaksanaan PKM }\end{array}$ & $\begin{array}{l}\text { - Menyusun rancangan kerja } \\
\text { - Melakukan survei lokasi PKM } \\
\text { - Koordinasi dengan sekolah } \\
\text { mitra }\end{array}$ \\
\hline 4 & Juli & $\begin{array}{l}\text { Persiapan } \\
\text { kebutuhan } \\
\text { administrasi }\end{array}$ & $\begin{array}{l}\text { - Membuat surat mnyurat } \\
\text { terkait dengan kegiatan PKM } \\
\text { - Pengiriman surat }\end{array}$ \\
\hline
\end{tabular}




\begin{tabular}{|c|c|c|c|}
\hline & & & $\begin{array}{l}\text { - Menyipkan daftar hadir } \\
\text { peserta }\end{array}$ \\
\hline 5 & Agustus & $\begin{array}{l}\text { Kegiatan PKM di } \\
\text { Sekolah Mitra }\end{array}$ & $\begin{array}{l}\text { - Tim pengabdian melakukan } \\
\text { sosialisai dan edukasi terkait } \\
\text { dengan terapi sensori integrasi } \\
\text { - Tim PKM kolaborasi dengan } \\
\text { ahli terapi sensori integrasi } \\
\text { membeikan pelatihan } \\
\text { - Tim PKM membimbing guru } \\
\text { melakukan praktik terapi } \\
\text { sensori integrasi kepada anak } \\
\text { tuna grahita }\end{array}$ \\
\hline 6 & $\begin{array}{l}\text { September- } \\
\text { Desember }\end{array}$ & $\begin{array}{l}\text { Laporan PKM dan } \\
\text { evaluasi kegiatan }\end{array}$ & $\begin{array}{l}\text { - } \text { Melakukan evaluasi } \\
\text { pelaksanaan PKM } \\
\text { - Menyusun laporan PKM } \\
\text { - Menyampaikan laporan PKM } \\
\text { kepada LPPM } \\
\text { - Membuat luaran PKM berupa } \\
\text { artikel pengabdian masyarakat }\end{array}$ \\
\hline
\end{tabular}

Kegiatan pengabdian dilakukan di tengah pandemic Covid-19. Maka dari itu jumlah guru yang mengikuti pelatihan dibatasi. Selain itu tim dosen PKM dan dan peserta harus mematuhi protocol kesehatan yang ditetapkan oleh pemerintah. Agar peserta merasa nyaman dalam mengikuti pelatihan maka ruang pelatihan memanfaatkan aula madrasah. Meskipun tidak terlalu besar tetapi cukup untuk menampung peserta. Jumlah peserta yang hadir sebanyak 16 guru dan tiga anak berkebutuhan khusus dari MI NW Tanak Beak.

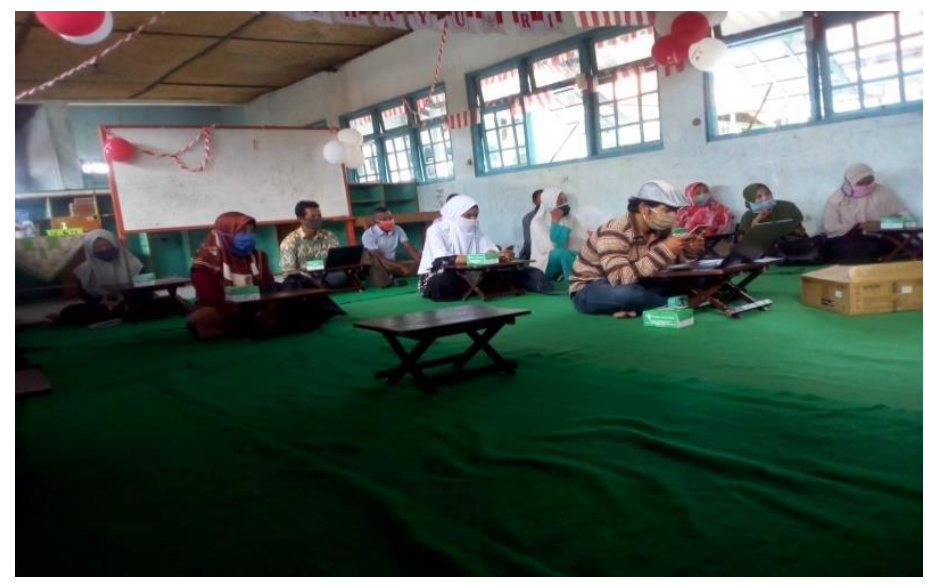

Gambar 2. Peserta Pelatihan Terapi Sensori Integrasi Level Basic

Hari pertama kegiatan pelatihan diawali dengan pemaparan materi dari tim PKM PGSD Universitas. Masing-masing tim memberikan kontribusi untuk memaparkan materi terkait dengan anak berkebutuhan khusus. Materi pertama yang disampaikan terkait dengan identifikasi anak berkebutuhan khusus. Materi kedua adalah merubah paradigma masyarakat 
terhadap layanan belajar anak berkebutuhan khusus. Materi ketiga terkait dengan optimalisasi peran guru dalam pelayanan anak berkebutuhan khusus. Materi terakhir adalah materi inti yang berisi tentang teori dasar terapi sensori integrasi.

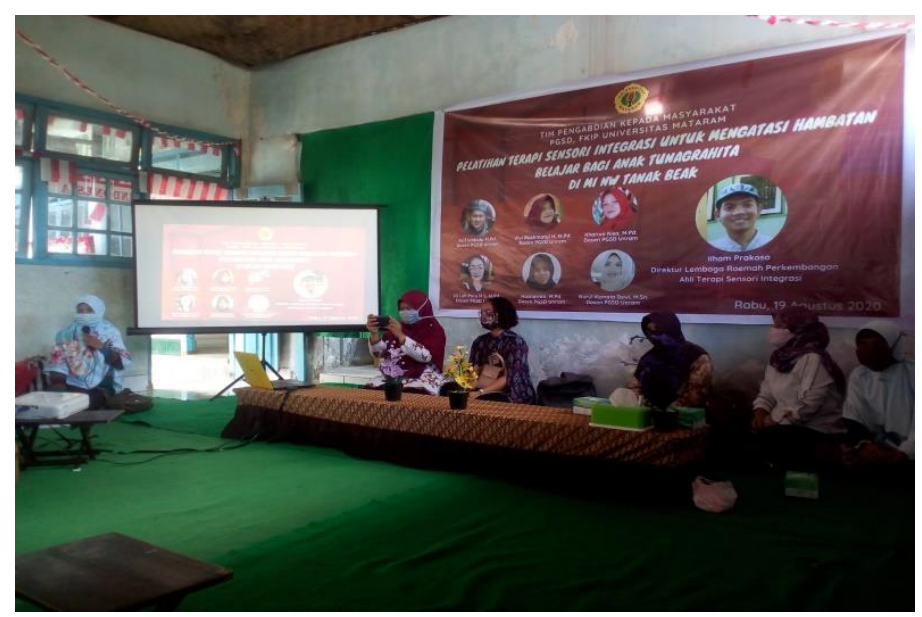

Gambar 3. Pemaparan materi oleh tim pengabdian PKM

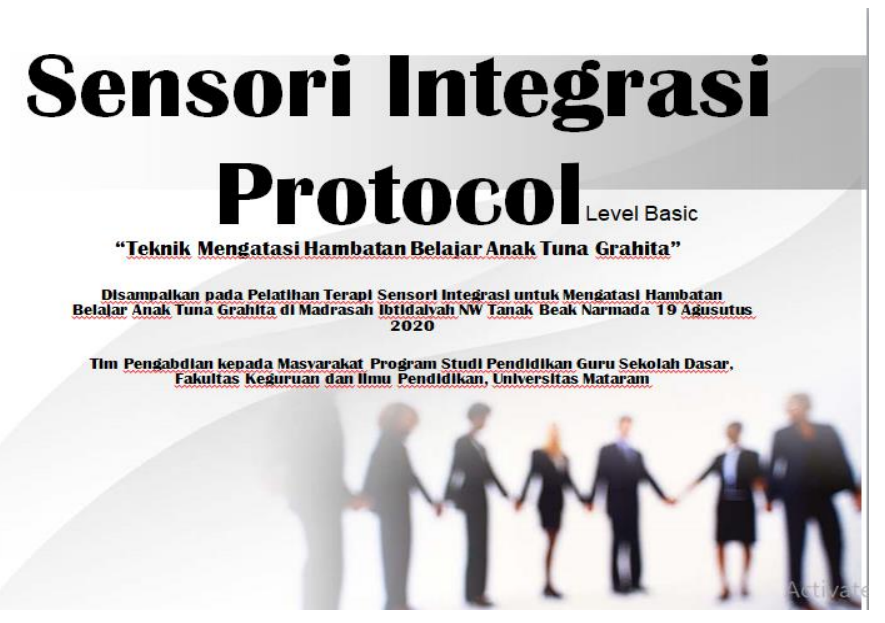

Gambar 4. Salah satu tampilan materi pelatihan

Hari kedua pelatihan diisi dengan kegiatan simulasi dan praktik langsung. Dalam kegiatan ini para peserta didampingi langsung oleh ahli terapi sensori integrasi dari Roemah Perkembangan NTB. Ahli terapi sensori integrasi memberikan memandu secara langsung peserta pelatihan dalam melakukan terapi. Sebelum melakukan simulasi instruktur memberikan contoh terlebih dahulu tahapan atau gerakan yang dapat digunakan untuk melakukan terapi sensori integrasi. Peserta pelatihan mendapat kesempatan untuk melakukan kegiatan terapi terhadap anak berkebutuhan khusus, terutama anak tuna grahita. 


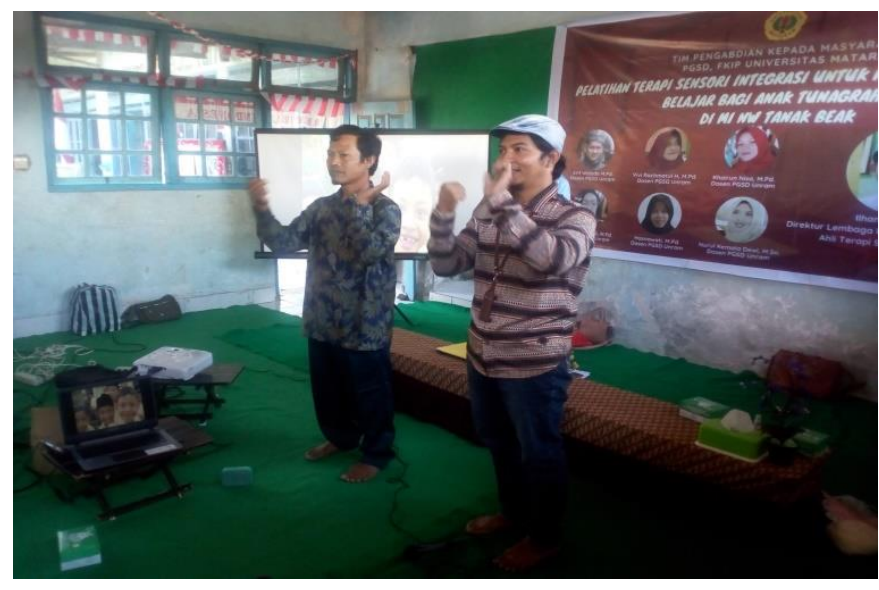

Gambar 5. Instruktur memandu para peserta melakukan integrasi sensorik

Pada sesi kedua ini tim pengabdian sengaja menghadirkan anak berkebutuhan khusus agar para guru mendapatkan gambaran secara nyata bagaimana melakukan terapi. Melalui cara ini diharapkan para guru tidak lagi merasa kesulitan dalam melakukan terapi pada saat proses pembelajaran.

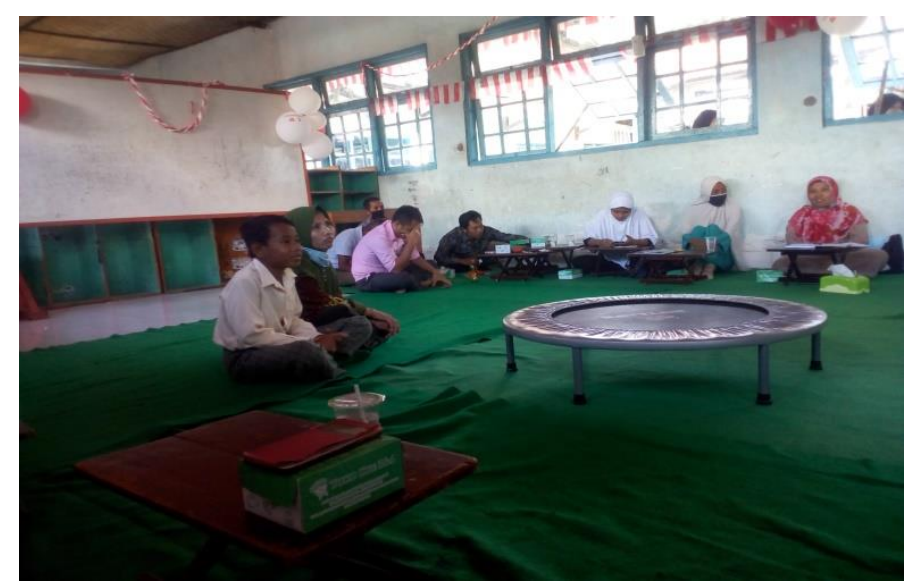

Gambar 6. Salah satu alat untuk terapi sensori integrasi

Sensori integrasi membutuhkan kerjasama sensor motorik, baik motorik halus maupun motorik kasar. Kemudian motorik tersebut diintegrasikan dengan beberapa indra agar dapat memerima dan memperoses informasi. terdapat beberapa gerakan dasar pada protocol sensori integrasi level basic antara lain: Pertama, Base Hopper. Gerakan ini merupakan gerakan konsentrasi yang mengintegrasikan antara kaki, tangan dan mata. Caranya adalah dengan melompat sesuai dengan level kemampuannya. Indikator keberhasilan treatment ini adalah selama 20 detik dapat mencapai keselarasan antara mata, kaki dan tangan. Kaki dan tangan seirama dengan instruksi, mata terlihat tenang dan nafas berjalan secara teratur. Kedua, Space Traveler. Gerakan ini merupakan gerakan stimulasi yang mengintegrasikan mata dan telinga dengan cara memutar anak dalam kondisi duduk bersila kurang lebih selama 20 detik. Indikator 
keberhasilannya adalah mata mulai tenang, mampu mengikuti instruksi dan nafas teratur. Ketiga, Brick House. Gerakan ini bertujuan untuk mengintegrasikan tulang punggung, tangan dan kepala. Brick house dilakukan seperti gerakan ketika sujud. Gerakan ini membutuhkan waktu 20 detik. Indikator keberhasilan gerakan ini adalah badan proporsional dan stabil, serta badan tidak banyak melakukan gerakan-gerakan yang tidak diperlukan. Keempat, Speed Recer. Treatment ini bertujuan untuk melatih konsentrasi dan target sasaran. Gerakan ini diambil dari fase perkembangan bayi ketike berguling. Indikator keberhasilan treatment ini adalah selama 20 menit mampu bergerak sesuai target, gerakan badan searah dengan anggota badan yang lain dan tidak melewati garis yang ditentukan. Kelima, Pluto Bounce. Treatment ini dilakukan dengan melembar bola ke atas dan ke bawah dengan mengintegrasikan tangan dan mata. Indikator keberhasilan treatment ini adalah selama 20 detik anak dapat menangkap tager dengan tepat, waktu yang ditentukan dapat dimaksimalkan, dan badan tidak keluar dari posisi target.

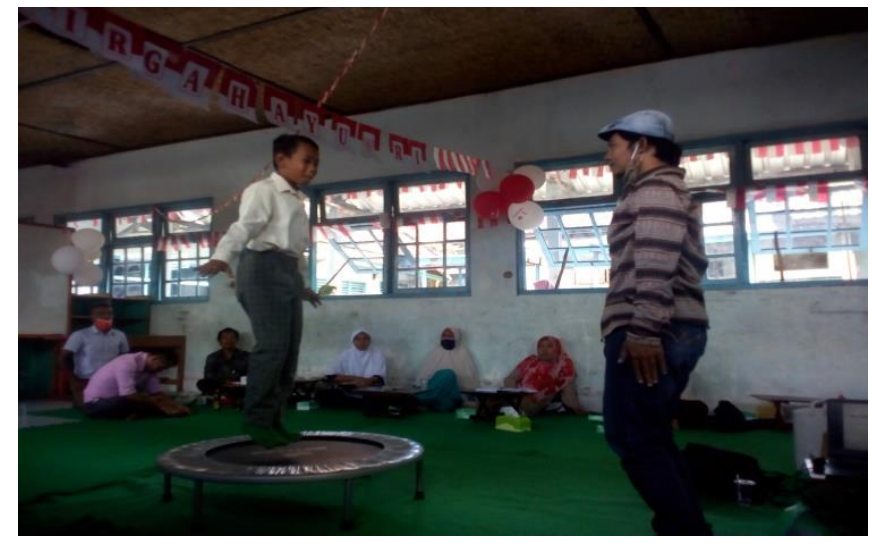

Gambar 7. Gerakan Base Hopper

\section{Diskusi}

Aspek terpenting dari kegiatan masyarakat ini adalah segi kebermanfaatan, kebutuhan, kemudahan penerapan, kesediaan penggunaan produk dan dapat menambah wawasan. Beberapa aspek di atas merupakan indikator keberhasilan dari program pengabdian masyarakat. Setelah kegiatan pengabdian peserta diberikan angket sebagai bahan evaluasi kegiatan. Respon dari peserta menjadi aspek yang terpenting sebagai tolok ukur keberhasilan kegiatan. Berikut ini dapat disajikan rekapitulasi angket kegiatan. 


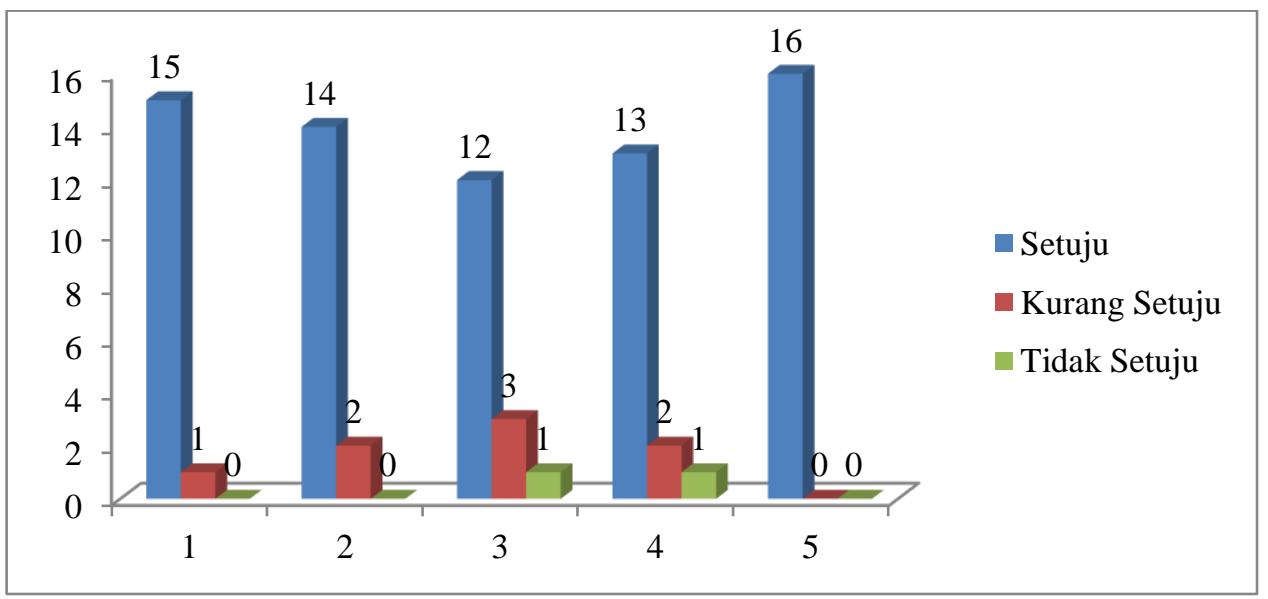

Gambar 8. Rekapitulasi angket kegiatan pelatihan

Aspek pertama yang dipertanyakan adalah segi kebermanfaatan. Peserta diberi pernyataan "Pelatihan terapi sensori integrasi sangat bermanfaat", 15 peserta menjawab setuju dan satu peserta masih kurang setuju. Pernyataan kedua yang diberikan adalah "Guru membutuhkan pelatihan terapi sensori integras", sebanyak 14 peserta menjawan setuju dan 2 peserta menjawab kurang setuju. Pernyataan ketiga yang diberikan berkaitan dengan aspek kemudahan. Peserta diberi pernyataan "Terapi sensor integrasi mudah diterapkan", sebanyak 12 peserta menyatakan setuju, 3 kurang setuju dan 1 pseserta menjawab tida setuju. Aspek keempat yang dipertanyakan berkaitan dengan kesediaan menggunakan produk pelatihan. Peserta diberi pernyataan "Saya bersedia menerapkan protocol terapi sensori integrasi dalam layanan belajar", sebanyak 13 peserta menjawa setju, 2 menjawab kurang setuju dan 1 peserta menjawab tidak setuju. Aspek terakhir yang dipertanyakan berkaitan dengan kontribusi pelatihan dalam menambah wawasan peserta. Pernyataan yang diberikan adalah "Pelatihan telah menambah wawasan saya dalam menangani anak tuna grahita" Pada bagian ini semua peserta menjawab setuju bahwa pelatihan dapat menambah wawasan guru dalam menangani anak tuna grahita.

Berdasarkan paparan data di atas dapat diketahui bahwa rata-rata peserta telah cukup puas dengan kegiatan pelatihan terapi sensori integrasi yang telah dilakukan. Namun demikian terdapat beberapa hal yang perlu menjadi catatan yaitu terkait dengan aspek kemudahan penerapan. Setidaknya ada 4 guru yang masih merasa kesulitan dalam menerapkan terapi sensori integrasi pada anak tuna grahita. Maka dari itu tim pengabdian masyarakat terus melakukan mentoring dan meningkatkan peran teman sejawat dalam proses aktualisasi di sekolah. Para guru yang telah memiliki kompetensi dalam melakukan terapi diharapakan dapat membantu guru lain yang masih mengalami kesulitan. 
Protokol terapi sensori integrasi diharapkan dapat diterapkan dengan baik oleh para guru di madrasah inklusi. Hal ini penting dilakukan agar proses pembelajaran dapat dilakukan dengan baik. Sebelum memulai pembelajaran sebaiknya peserta didik dilakukan integrasi sensor motornya agar dapat menerima informasi dengan baik. Sangat penting bagi setiap indera bisa berfungsi sesuai dengan tugas perkembangnnya yang menghasilkan sebuah informasi dan selanjutnya direspon oleh motorik kasar. Tersambungnya seluruh fungsi kerja indera manusia dengan sistem sensor motor dapat meningkatkan konsentrasi dan fokus anak-anak dalam belajar. Hal ini sesuai dengan beberapa penelitian terdahulu yang menyatakan bahwa penggunaan terapi sensori integrasi efektif dalam membantu anak tuna grahita membentuk fokus dan konsentrasi yang lebih baik (Komariah 2018). Penanganan yang terlambat terhadap anak tuna grahita dapat menyebabkan gangguan fungsional yang lebih kompleks. Dalam sebuah penelitian disebutkan bahwa gangguan dalam pemrosesan sensori dapat menghambat perkembangan dan dapat menimbulkan disfungi integrasi (Waiman et al. 2011). Salah satu dampaknya adalah gangguan komunikasi dan gangguan belajar serius (Ainnayyah et al. 2019). Maka dari itu dengan adanya pelatihan ini diharapkan guru dapat memberikan layanan belajar yang maksimal untuk membantu kebutuhan anak tuna grahita.

\section{Kesimpulan}

Berdasarkan hasil dan diskusi dapat disimpulkan bahwa kegiata pelatihan terapi sensori integrasi level basic di MI NW Tanak Beak dapat berjalan dengan lancar. Adapun indikator keberhasilan kegiatan pengabdian masyarakat ini dapat terlihat dari aspek segi kebermanfaatan, kebutuhan, kemudahan penerapan, kesediaan penggunaan produk dan kontribusi dalam menambah wawasan. Dari beberapa aspek yang ditentukan tersebut rata-rata sudah cukup tinggi sehingga kegiatan pengabdian kepada masyarakat dapat dianggap telah berhasil.

\section{Daftar Referensi}

Ainnayyah, Refiana, Rohma Isni Maulida, Amelia Astian Ningtyas, and Istiana Istiana. 2019. "Identifikasi Komunikasi Anak Berkebutuhan Khusus Dalam Interaksi Sosial." JPI (Jurnal Pendidikan Inklusi) 3(1):48-52.

Fedulova, Inna, Valentina Ivanova, Olga Atyukova, and Vladimir Nosov. 2019. "Inclusive Education as a Basis for Sustainable Development of Society." Journal of Social Studies Education Research 10(3):118-35. 
Idris, Nurwahyuni and Fitriani. 2018. "Sosial Skill Analysis In Children With Special Needs." 6:143-49.

Indah, Avrima Nur and Siti Masitoh. 2013. "Sensory Integration Terhadap Kemampuan Bicara Anak Tunagrahita Sedang." Jurnal Pendidikan Khusus 3(3):1-6.

Komariah, Fitri. 2018. "Program Terapi Sensori Integrasi Bagi Anak Tunagrahita Di Yayasan Miftahul Qulub.” INKLUSI 5(1):45-72.

Mayasari, Mayasari. 2016. "Implementasi Kurikulum 2013 Pada Anak Berkebutuhan Khusus (ABK) Di SD Muhammadiyah Sapen Yogyakarta.” INKLUSI 3(1):1-18.

Pujaningsih, Pujaningsih. 2019. "Penyiapan Calon Guru Untuk Anak Berkebutuhan Khusus Di Indonesia: Kondisi Saat Ini Dan Tantangan.” JPK (Jurnal Pendidikan Khusus) 15(1):24-33.

Sriwarthini, N. Putu Nina, K. Sri Kusuma Wardani, Aisa Nikmah Rahmatih, Nurwahidah, and Fitri Puji Astria. 2020. "Pemenuhan Hak Anak Berkebutuhan Khusus Dalam Implementasi Program Pendidikan Inklusif Di SDN 20 Mataram." Progres 1(2):10614.

Waiman, Elina, Hartono Gunardi, Rini Sekartini, and Bernie Endyarni. 2011. "Sensori Intergrasi : Dasar Dan Efektifitas Terapi.” Sari Pediatri 13(2):129-36.

Wardah, Erika Yunia. 2019. "Peranan Guru Pembimbing Khusus Lulusan Non-Pendidikan Luar Biasa (PLB) Terhadap Pelayanan Anak Berkebutuhan Khusus Di Sekolah Inklusi Kabupaten Lumajang.” JPI (Jurnal Pendidikan Inklusi) 2(2):93-108.

Wardani, K. Sri Kusuma, Ni Luh Putu Nina Sriwarthini, Aisa Nikmah Rahmatih, Fitri Puji Astria, and Nurwahidah. 2020. "Pelaksanaan Program Pendidikan Inklusif Bagi Anak Berkebutuhan Khusus Di SDN 20 Mataram.” Progres Pendidikan 1(2):99-105.

Widodo, Arif. 2020a. "Penyimpangan Perilaku Sosial Ditinjau Dari Teori Kelekatan Bowlby (Studi Kasus Terhadap Anak Tenaga Kerja Wanita Di Lombok Barat).” ENTITA: Jurnal Pendidikan Ilmu Pengetahuan Sosial Dan Ilmu-Ilmu Sosial 2(1):35-50.

Widodo, Arif. 2020b. "Proses Internalisasi Nilai-Nilai Karakter Madrasah Inklusi ( Studi Deskriptif Di MI NW Tanak Beak Lombok Barat ).” JURNAL PENDIDIKAN ISLAM AL-ILMI 3(1):27-38.

Widodo, Arif, Linda Feni Haryati, Mohammad Archi Maulyda, Umar, and Muhammad Erfan. 2020. "Proses Identifikasi Peserta Didik Berkebutuhan Khusus Di MI NW Tanak Beak Kabupaten Lombok Barat.” Progres Pendidikan 1(2):63-71.

Widodo, Arif, Dyah Indraswati, Deni Sutisna, Nursaptini Nursaptini, and Setiani Novitasari. 2020. "Identifikasi Bakat Peserta Didik Berkebutuhan Khusus (PDBK) Di Madrasah Inklusi Kabupaten Lombok.” JPI (Jurnal Pendidikan Inklusi) 3(2):102-16. 